\title{
Mutações Legais no Direito Eleitoral: repercussões no sistema das invalidades eleitorais e na renovação das eleições
}

\author{
Legal Mutations in Election Law: repercussions for the validity and \\ repeat of elections
}

João Andrade Neto

Resumo: O artigo trata do sistema de invalidades e de defesa da autenticidade das eleições. Propõe-se a estudar dois casos de mutação legal relativos à interpretação e à aplicação do art. 224, do Código Eleitoral - referentes, portanto, à invalidação da votação e à convocação de novas eleições pela Justiça Eleitoral. Por analogia ao conceito de mutação constitucional, de Jellinek (1991), as mutações legais se definem como alterações das normas infraconstitucionais sem mudança textual formal, provocadas não pelos legisladores, mas pelos intérpretes, sem que estes demonstrem consciência de que o fazem. O primeiro caso estudado consiste na redução das causas de invalidação da votação na circunscrição como um todo, o segundo, no desaparecimento dos meios autônomos para a decretação de invalidade. Resulta dessas mutações o paradigma atual acerca do tema, consubstanciado nos ED no RESPE 139-25. Nos termos dessa decisão proferida pelo TSE em 2016, somente o indeferimento do registro ou a cassação do registro, do diploma ou do mandato de candidato eleito autorizam a convocação de eleições suplementares. Confrontando-se a doutrina e a jurisprudência anteriores e posteriores à $\mathrm{CRFB} / 88$, demonstra-se que esse paradigma se estabeleceu sem que fossem enfrentadas e superadas as premissas teóricas e jurisprudenciais da concepção precedente.

Palavras-chave: Mutação legal. Causas de invalidade da votação. Renovação das eleições. Eleições suplementares.

\begin{abstract}
This essay deals with the Brazilian system of laws on the validity and authenticity of elections. Its purpose is to analyse two cases of legal mutation regarding the interpretation and application of article 224 Electoral Code, which authorizes the Election Justice to invalidate and call for the repeat of elections. By analogy to the concept of constitutional mutation (JELLINEK), legal mutation are defined as changes in infra-constitutional norms that do not result from authoritative alteration passed by the legislative body. They are the result of the interpreters' activity instead, although these interpreters do not show awareness of the process. The first case the essay analyses consists in the reduction of the admitted causes for invalidating the election in the entire electoral jurisdiction; the second consists in the disappearing of the appeals of invalidation. The current understanding of the Superior Election Court on these matters, stated in ED RESPE 139-25, judged 2016, derives from these mutations. In this case, the Court ruled that elections must be repeated only if elected candidates have their registration or mandates denied or cancelled by the Election Justice. Comparing specialized literature and case-law from before and after the Federal Constitution, this essay demonstrates that the current practice and understating on these matters were set without properly overruling the preceding conception.
\end{abstract}

Keywords: Legal mutations. Invalidation of election. Repeal of elections. Supplementary elections.

Artigo recebido em 1ํjul. 2017 e aprovado em 25 set. 2017. 


\section{Introdução}

Este artigo discute algumas inconsistências das construções doutrinária e jurisprudencial referentes à aplicação do art. 224, do Código Eleitoral (CE). Sustenta-se que, desde pelo menos a promulgação da CRFB/88, o Direito Eleitoral relativo ao sistema de invalidades e de defesa da autenticidade das eleições passou por mutações legais que não foram inteiramente compreendidas e assimiladas pela doutrina e pela jurisprudência, mesmo antes da última Minirreforma eleitoral, de 2015. Por analogia ao conceito de mutação constitucional de Jellinek (1991, p. 7), define-se mutação legal como a mudança da norma infraconstitucional, ou legal, sem alteração textual formal, provocada por fatos "que não têm de vir acompanhados pela intenção, ou consciência, de tal mutação.”.

O conceito de mutação legal contrapõe-se ao de reforma legislativa. A mutação legal é fruto da atividade dos intérpretes; no caso sob análise ela decorre de guinadas bruscas na jurisprudência do TSE. Já a reforma legislativa, assim definida por analogia ao conceito de reforma constitucional de Jellinek (1991, p. 7), consiste na modificação dos textos legais "produzida por ações voluntárias e intencionadas" do próprio legislador. O Direito Eleitoral se modifica não somente pelas reformas eleitorais que se sucedem a cada eleição - como a promovida pela Lei no 13.165 , em 2015 -, mas também, pelas mutações legais, ou mudanças no entendimento dos tribunais e da doutrina, acerca de conceitos e institutos desse ramo jurídico.

O problema é que, enquanto as reformas eleitorais recebem ampla atenção dos eleitoralistas, e frequentemente reverberam mesmo na mídia não especializada, as mutações legais no Direito Eleitoral são pouco ou nada estudadas, apesar de impactarem diretamente a interpretação e, consequentemente, a aplicação do Direito das eleições.

Advirta-se que não é objetivo deste trabalho problematizar o conceito de mutação constitucional ou a teoria de Jellinek (1991). Remete-se o leitor, porém, a autores que o fazem ${ }^{1}$. No que impacta esta pesquisa, parte-se do suposto de que as mutações legais possuem as seguintes características:

- são causadas por fatos ou elementos externos à argumentação jurídica - como a implementação do sistema eletrônico de votação e das urnas eletrônicas -, os quais são apreensíveis a partir

${ }^{1}$ Ver, por exemplo, Bulos (1996), Pedra (2009), Pedron (2012) e Vecchi (2005). 
da perspectiva do observador (ANDRADE NETO, 2016b, p. 870-871) e, portanto, objeto da sociologia ou historiografia jurídicas;

- repercutem na argumentação jurídica, internamente, na medida em que implicam significativas mudanças na interpretação dos textos legais e, consequentemente, no conteúdo propriamente normativo (proibições, permissões e obrigações) deles derivados;

- ocorrem pela ação dos intérpretes do texto - juízes, promotores, acadêmicos e demais participantes dos debates acerca do que o Direito é ou diz (ANDRADE NETO, 2016b, p. 870-871), embora esses, individualmente considerados, não necessariamente tenham consciência do papel que exercem quando operam as mudanças. As mutações legais, ou interpretativas, são, portanto, "inorganizadas", pois ocorrem "de um modo implícito, espontâneo, quase imperceptível, sem seguir formalidades legais.” (BULOS, 1996, p. 28).

A inconsciência é elemento essencial do conceito, que o diferencia do ativismo judicial ou da deliberada instrumentalização da jurisdição, praticada por quem voluntária e arbitrariamente submete a função jurisdicional a resultados desejados, ou a exerce a fim de realizar alguma concepção pessoal de bem comum (ANDRADE NETO, 2016a, p. 280-281; CRUVINEL, 2013, p. 124-136). Por inconsciência, alude-se não à ausência de representação subjetiva, individual, do fenômeno, mas ao fato de que ele não se apresenta como tal à comunidade de intérpretes. Assim, embora não seja possível afirmar ao certo se os indivíduos que operam as mudanças tinham ou não consciência dela, eles se comportam como se não tivessem. Em se tratando de alterações jurisprudenciais, como no caso em estudo, os tribunais promovem verdadeiras guinadas em sua própria jurisprudência sem o dizer expressamente, isto é, desconsiderando por completo julgados anteriores e a ratio decidendi que os orientava.

É precisamente em razão da falta de consciência da comunidade de intérpretes diante da mutação que o problema destacado por este trabalho se coloca. A mutação legal do Direito Eleitoral operada pela jurisprudência de um tribunal como o TSE, e respaldada pela doutrina, ocorre sem que as premissas da interpretação anterior sejam enfrentadas e superadas, logo, sem o que, a partir da entrada em vigor do novo Código de Processo Civil (CPC), se convencionou chamar de overruling. 
Nesse processo, perde-se a possibilidade de reconstruir o sentido histórico dos conceitos ou institutos jurídicos como uma cadeia de sucessivas concepções que dialogam entre si, as seguintes com as anteriores. Como consequência, são notáveis os prejuízos para a integridade do Direito Eleitoral e para a segurança jurídica dos indivíduos a ele submetidos.

Os dois casos de mutação legal eleitoral selecionados neste trabalho dizem respeito ao sistema eleitoral de invalidades e de defesa da autenticidade das eleições. São eles: a redução do sentido do art. 222, do CE, que passou a ser lido como se as causas de anulabilidade nele previstas se restringissem aos ilícitos eleitorais típicos (abuso de poder, conduta vedada, captação de sufrágio etc.), e não incluíssem outros vícios do processo eleitoral; e o desaparecimento, na doutrina e na jurisprudência, dos meios autônomos para a decretação da invalidade de atos eleitorais, as arguições de invalidade.

Resultam dessas mutações as seguintes ideias, que compõem o paradigma hoje dominante no Direito Eleitoral:

- só o indeferimento do registro de candidato eleito ( $\left(3^{\circ}\right.$ do art. 175 do CE), ou a cassação do registro, do diploma ou do mandato de candidato eleito, em virtude da prática de um ilícito eleitoral típico (art. 222, do CE) autorizam a convocação de eleições suplementares;

- a invalidação da votação e a consequente renovação das eleições é, necessariamente, efeito externo da decisão judicial que indefere o registro de candidatura, ou julga procedentes as ações eleitorais típicas: a ação de impugnação do registro de candidatura (AIRC), o recurso contra expedição de diploma (RCED), a ação de impugnação do mandato eletivo (AIME), a ação de investigação judicial eleitoral (AIJE) ou a representação prevista no art. 22, da $\operatorname{LC~n}^{\circ}$ 64/90.

Ambas as ideias estão expressas nos Embargos de Declaração no Recurso Especial Eleitoral (ED no RESPE) 139-25, nos quais o TSE estabeleceu o paradigma vigente para interpretação e aplicação do art. 224, do CE (BRASIL, 2016).

A argumentação desenvolvida se estrutura da seguinte forma: a seção seguinte expõe o sistema eleitoral de invalidades e de defesa da autenticidade das eleições, explorando suas inconsistências, que autorizam divergências doutrinárias e jurisprudenciais. A seção 3 trata da primeira mutação legal 
selecionada: a redução do sentido do art. 222, do CE, que limitou as anulabilidades passíveis de ocasionar a renovação das eleições àquelas decorrentes dos ilícitos eleitorais típicos. Já a seção 4 discute a segunda mutação legal aqui destacada: o desaparecimento dos meios autônomos para a decretação da invalidade da votação, que só subsiste no sistema eleitoral como efeito externo da decisão judicial que julga as ações eleitorais de arguição de inelegibilidade ou as ações para apuração dos ilícitos eleitorais típicos. Ao final, por meio da comparação entre concepções doutrinárias e jurisprudenciais atuais e anteriores, pretende-se demonstrar que a evolução dos conceitos e da prática eleitoral a respeito dessas matérias ocorreu sem que as premissas da interpretação superada fossem enfrentadas, criando novas inconsistências que dificultam a compreensão sistêmica do Direito Eleitoral, e comprometem a segurança jurídica dos indivíduos a ele submetidos.

\section{O Sistema das Invalidades Eleitorais e da Defesa da Autenticidade das Eleições}

Inicialmente, cumpre entender como as regras relativas à renovação de eleições previstas no Código Eleitoral, se relacionam ao sistema eleitoral das invalidades. A questão já era de interesse da doutrina mesmo antes da Lei no ${ }^{\circ}$ 13.165/15 2 , embora, anteriormente à CRFB/88, recebesse tratamento secundário. É esclarecedor comparar o espaço destinado à renovação das eleições pela geração de 'eleitoralistas' que adquiriram renome antes de 1988 com a importância dada ao tema pelos juristas cujas obras mais famosas sucederem à Constituição Federal.

O caso mais notável é o de Fávila Ribeiro e de seu manual "Direito Eleitoral", cuja primeira edição data de 1976. A terceira edição da obra, lançada em 1988, tem 620 páginas e dedica um capítulo à "Invalidade de Atos Eleitorais", destaca-se, no entanto, que as eleições suplementares decorrentes da anulação de votos que ultrapassasse a metade da votação na circunscrição só são mencionadas em uma página (RIBEIRO, 1988, p. 319).

Compare-se com o espaço destinado à matéria por Rodrigo López

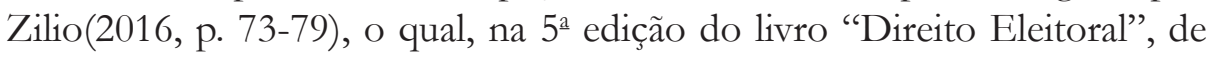
2016, dedica 6 páginas especificamente à renovação das eleições decorrente da invalidade dos votos. Merece destaque, ainda, José Jairo Gomes(2010, p. 581-594, 2016, p. 841-854), nas edições quarta e décima segunda do livro

${ }^{2}$ Vejam-se, por exemplo, Almeida Neto (2014, cap. 3), Gomes (2009) e Zílio (2013). 
“Direito Eleitoral”, de 2010 e 2016, respectivamente, reserva à matéria um capítulo inteiro, ou 13 páginas.

Na realidade, a atenção dedicada ao tema da convocação de novas eleições cresce à medida que aumentam o número de cassações de registros, mandatos e diplomas.

A relação entre a invalidação de votos - decorrente ou não da cassação de registros, mandatos e diplomas - e a convocação de novas eleições se estabelece explicitamente em razão do disposto no caput do art. 224 do CE, cuja redação se mantém inalterada desde a promulgação do Código Eleitoral, em 1965:

Art. 224. Se a nulidade atingir a mais de metade dos votos do país nas eleições presidenciais, do Estado nas eleições federais e estaduais ou do município nas eleições municipais, julgar-se-ão prejudicadas as demais votaçoes e o Tribunal marcará dia para nova eleição dentro do prazo de 20 (vinte) a 40 (quarenta) dias. (destaque nosso)

O caput do art. 224 do CE estipula uma relação de imputação - ou de causalidade jurídica (SCHREIBER, 2013, p. 55) - entre a invalidação de votos, à qual se refere como "nulidade", e a convocação de novas eleições. Esta é consequência, ou efeito “anexo” (ZILIO, 2016, p. 73), externo ou extrínseco, legalmente atribuído àquela e, portanto, inafastável, indissociável e juridicamente necessário ${ }^{3}$. Tal relação não é aleatória, mas orientada a um fim, como, de resto, toda legislação eleitoral o é. O art. 219, do CE dispõe que " $\mathrm{Na}$ aplicação da lei eleitoral o juiz atenderá sempre aos fins e resultados a que ela se dirige, abstendo-se de pronunciar nulidades sem demonstração de prejuízo.”(BRASIL, 1965).

A finalidade geral das nulidades e anulabilidades eleitorais é indicada pelo princípio constitucional da legitimidade. Para proteger a autenticidade das eleições tanto em sentido formal quanto substantivo, o Código Eleitoral estabeleceu um sistema de invalidades. As inconsistências desse sistema estão no cerne dos problemas relativos à convocação de novas eleições e à interpretação da nova redação do art. 224, do CE.

\footnotetext{
${ }^{3} \mathrm{O}$ conceito de efeitos jurídicos extrínsecos, em oposição aos intrínsecos, é essencial a vários subsistemas eleitorais. Sobre sua importância para o subsistema das inelegibilidades, ver Gresta at al. (2012, p. 207).
} 


\subsection{O Princípio da Autenticidade das Eleições}

O "princípio constitucional da autenticidade eleitoral” (SALGADO, 2010, p. 36)aparece na literatura especializada com diferentes nomes, às vezes como "integridade" (ALVIM, 2015), outras, como verdade, "veracidade ou sinceridade"(ZILIO, 2013), por exemplo. A própria CRFB/88 não fala em autenticidade, mas em "normalidade e legitimidade das eleições” (BRASIL, 1988). O $\$ 9^{\circ}$ do art. 14 da CRFB/88 expressamente determina que o Poder Legislativo promulgue uma lei complementar que crie hipóteses de inelegibilidade, a fim de proteger a normalidade e a legitimidade das eleições.

De qualquer maneira, independentemente do nome que se dê à autenticidade, há duas maneiras de compreender o conceito. O primeiro sentido desse termo é formal: ele supõe que as eleições são autênticas se efetivamente conduzidas em conformidade com o devido processo eleitoral constitucional e legal. Ou seja, as eleições são legítimas se todo o processo eleitoral se desenvolve de acordo com o que está previsto em lei ou na Constituição, desde o registro de candidaturas até a diplomação dos eleitos, passando pela votação propriamente dita. Nesse sentido, autenticidade significa respeito às regras do jogo, ou aos procedimentos a serem seguidos, os quais, de todo modo, "devem ser amparados em garantias de igualdade e de liberdade, sob pena de ilegitimidade do sistema representativo." (SALGADO, 2010, p. 33.)

O segundo sentido desse termo é substantivo e diz respeito ao resultado das eleições. Ele tem de ser fidedigno, isto é, corresponder à real vontade do eleitor, que só pode vir à tona em um ambiente jurídico-institucional que garanta a liberdade de consciência e reserve ao indivíduo um espaço protegido para reflexão (SALGADO, 2010, p. 41-48). Esse princípio impõe que fatores como os "recursos econômicos dos candidatos, seu acesso aos meios de comunicação de massa e o exercício de cargo ou função pública por algum deles" sejam indiferentes para o resultado da votação, de modo que somente fatores como "os programas políticos e as qualidades dos líderes [...]” sejam "considerados relevantes na disputa eleitoral.”(SALGADO, 2010, p. 34.)

Para proteger a autenticidade das eleições em ambos os sentidos, tanto formal quanto substantivo, o legislador se valeu não apenas das inelegibilidades, como exige o $\$ 9^{\circ}$ do art. 14 da CRFB/88, mas também do 
sistema das invalidades eleitorais, que abrangem nulidades e anulabilidades. Nas palavras de Ribeiro (1988, p. 395), “a invalidação é um corretivo de elevado alcance para coibir atentados à liberdade do eleitor e à lisura dos pleitos.”. Segundo o jurista, trata-se de uma sanção que visa “evitar os desvirtuamentos à vontade do eleitorado [...]" e "desestimular tudo o que possa desfigurar a verdade eleitoral.” (RIBEIRO, 1988, p. 395). Esse sistema de invalidades é integrado pelos arts. 165, 175 e 219 a 223, do CE.

\subsection{O Sistema das Invalidades Eleitorais e suas Inconsistências}

A despeito de agruparem-se aqui os arts. 165, 175 e 219 a 223, do CE em um sistema, as inconsistências decorrentes de sua interpretação conjunta são patentes. Tentando se apegar a algum critério que ofereça um mínimo de coerência ao tratamento dado pelo Código Eleitoral às hipóteses de invalidade, a doutrina tenta extrair sentido da letra da lei.

Por um lado, eleitoralistas como Bramraiter (2013, p. 65-69), diferenciam entre as invalidades que afligem o voto ( $\$ 1^{\circ}$ do art. 175 do $\mathrm{CE}$ ), a cédula (caput do art. 175 do CE) e a votação (arts. 220 e 221, do CE). Por outro lado, Gomes (2016, p. 618-619, 626-627) separa as hipóteses textuais de nulidade (arts. 175 e 220, do CE) das de anulabilidade (art. 221 daquele diploma). A nulidade poderia ser alegada de ofício pela Junta Eleitoral ou declarada, mediante provocação, pelo órgão judicial, e teria efeitos retroativos, ex tunc; já anulabilidade só poderia ser reconhecida mediante arguição e teria efeitos ex nunc, não retroativos.

Esse esforço interpretativo tem sido em vão, porém, pois, "algumas vezes, o termo nulidade é usado [pelo Código Eleitoral] em sentido amplo, identificando-se com invalidade, abarcando, pois, a anulabilidade. Por processo metonímico, tomou-se a espécie pelo gênero." (GOMES, 2009, p. 72).

As inconsistências do sistema das invalidades eleitorais são em muito decorrentes dessa má-técnica legislativa, como se exporá a seguir.

\subsubsection{Nulidades previstas no Código Eleitoral}

$\mathrm{O}$ art. 175, do CE, que trata de hipóteses de nulidade, exemplifica bem a falta de apuro técnico do legislador. De acordo com Ribeiro (1988, p. 397), nele "figuram as nulidades referentes a vícios sobre os sufrágios individualmente considerados.”. Mas isso só é parcialmente verdadeiro. De fato, 
os $\iint 1^{\circ}$ e $2^{\circ}$ do art. 175 do CE tratam da nulidade dos votos decorrente do mero erro do eleitor ao preencher a cédula de votação para as eleições majoritária e proporcional, respectivamente ${ }^{4}$. Entretanto, o caput e os incisos do art. 175 do CE tratam da nulidade das cédulas de votação, e os efeitos dos vícios a que se referem têm potencial de dano para o processo eleitoral maior do que o do simples erro do votante, pois podem indicar fraude. É o caso da votação em cédulas não oficiais ou não autenticadas ou passíveis de levar à identificação do eleitor ${ }^{5}$. Nestes casos, pode-se estar diante de um ilícito eleitoral doloso, e não do mero erro ou descuido do eleitor ${ }^{6}$.

A má-técnica legislativa de agrupar em um mesmo artigo - e assim sugerir o mesmo tratamento jurídico a - situações cuja gravidade é tão diversa só não gera mais estranheza que a leitura dos parágrafos seguintes, pois, apesar dos problemas mencionados, o caput e os $\iint 1^{\circ}$ e $2^{\circ}$ do art. 175 do CE têm algo em comum: tratam de invalidades decorrentes de vícios nos meios ou instrumentos físicos envolvidos no ato de votar.

A manifestação do eleitor não se aperfeiçoou porque faltava algum elemento essencial: ou não podia ser conhecida, era defeituosa, por-

\footnotetext{
${ }^{4} \int 1^{\circ}$ Serão nulos os votos, em cada eleição majoritária: I - quando forem assinalados os nomes de dois ou mais candidatos para o mesmo cargo; II - quando a assinalação estiver colocada fora do quadrilátero próprio, desde que torne duvidosa a manifestação da vontade do eleitor. $\int 2^{\circ}$ Serão nulos os votos, em cada eleição pelo sistema proporcional: I - quando o candidato não for indicado, através do nome ou do número, com clareza suficiente para distingui-lo de outro candidato ao mesmo cargo, mas de outro partido, e o eleitor não indicar a legenda; II - se o eleitor escrever o nome de mais de um candidato ao mesmo cargo, pertencentes a partidos diversos, ou, indicando apenas os números, o fizer também de candidatos de partidos diferentes; III - se o eleitor, não manifestando preferência por candidato, ou o fazendo de modo que não se possa identificar o de sua preferência, escrever duas ou mais legendas diferentes no espaço relativo à mesma eleição.” (BRASIL, 1965).

${ }^{5}$ Art. 175. Serão nulas as cédulas: I - que não corresponderem ao modelo oficial; II - que não estiverem devidamente autenticadas; III - que contiverem expressões, frases ou sinais que possam identificar o voto." (BRASIL, 1965).

${ }^{6}$ Observe-se que é um erro considerar que os atos eleitorais inválidos são lícitos e reservar a expressão "ilícitos eleitorais" apenas aos ilícitos eleitorais típicos, como, por exemplo, o abuso de poder, as condutas vedadas ou a captação ilícita de sufrágio. Nas palavras de Mello (2006, p. 51), "se a contrariedade a direito constitui elemento cerne da ilicitude e é, também, o fundamento da invalidade dos atos jurídicos, não é possível extrair-se outra conclusão senão a de que o ato jurídico inválido integra o gênero fato jurídico ilícito lato sensu." Por essa razão, considera-se que "a invalidade [...] tem o caráter de um sanção". (MELLO, 2006, p. 52).
}

Resenha Eleitoral (Florianópolis), v. 21, n. 1, p. 69-94, nov. 2017 
que a cédula não fora adequadamente marcada, por exemplo; ou não era confiável, porque se materializou por meio questionável ou duvidoso. Em todo caso, os votos nulificados não são apuráveis. A mesma lógica orienta as hipóteses do art. 220, do CE, o qual prevê nulidades da votação decorrentes do desrespeito a formalidades que a lei considera essenciais ${ }^{7}-$ o que, estritamente falando, deveria implicar a inexistência do ato (GOMES, 2009, p. 73). Faz sentido, portanto, que se aplique a essas invalidades o art. 223, do CE, que torna a Junta Eleitoral responsável pela decretação da nulidade ${ }^{8}$, uma vez que ela é também o órgão competente para o exame das cédulas e anúncio dos votos brancos e nulos durante a apuração ${ }^{9}$.

Quão diversa é a lógica que orienta os $\iint 3^{\circ}$ e $4^{\circ}$ do art. 175 do $\mathrm{CE}^{10}$. Nesse caso, não recaem dúvidas ou suspeitas sobre a vontade do

\begin{abstract}
7 “Art. 220. É nula a votação: I - quando feita perante mesa não nomeada pelo juiz eleitoral, ou constituída com ofensa à letra da lei; II - quando efetuada em folhas de votação falsas; III - quando realizada em dia, hora, ou local diferentes do designado ou encerrada antes das 17 horas; IV - quando preterida formalidade essencial do sigilo dos sufrágios. V quando a seção eleitoral tiver sido localizada com infração do disposto nos $\int \S 4^{\circ}$ e $5^{\circ}$ do art. 135. Parágrafo único. A nulidade será pronunciada quando o órgão apurador conhecer do ato ou dos seus efeitos e o encontrar provada, não lhe sendo lícito supri-la, ainda que haja consenso das partes." (BRASIL, 1965). Note-se que, apesar de o caput se referir à nulidade da votação, os incisos I e III tratam de hipóteses que "[...] a rigor são de inexistência."
\end{abstract} (GOMES, 2016, p. 616).

${ }^{8}$ Art. 223. A nulidade de qualquer ato, não decretada de ofício pela Junta, só poderá ser arguida quando de sua prática, não mais podendo ser alegada, salvo se a arguição se basear em motivo superveniente ou de ordem constitucional. $\$ 1^{\circ}$ Se a nulidade ocorrer em fase na qual não possa ser alegada no ato, poderá ser arguida na primeira oportunidade que para tanto se apresente. $\int 2^{\circ}$ Se se basear em motivo superveniente deverá ser alegada imediatamente, assim que se tornar conhecida, podendo as razões do recurso ser aditadas no prazo de 2 (dois) dias. $\$ 3^{\circ}$ A nulidade de qualquer ato, baseada em motivo de ordem constitucional, não poderá ser conhecida em recurso interposto fora do prazo. Perdido o prazo numa fase própria, só em outra que se apresentar poderá ser arguida.” (BRASIL, 1965).

${ }^{9}$ Art. 174. As cédulas oficiais, à medida em que forem sendo abertas, serão examinadas e lidas em voz alta por um dos componentes da Junta. \1 Após fazer a declaração dos votos em branco e antes de ser anunciado o seguinte, será aposto na cédula, no lugar correspondente à indicação do voto, um carimbo com a expressão "em branco", além da rubrica do presidente da turma. \2 O mesmo processo será adaptado para o voto nulo.” (BRASIL, 1965). ${ }^{10}$ Art. 175 [...]. \3º Serão nulos, para todos os efeitos, os votos dados a candidatos inelegíveis ou não registrados. $\int^{\circ}{ }^{\circ} \mathrm{O}$ disposto no parágrafo anterior não se aplica quando a decisão de inelegibilidade ou de cancelamento de registro for proferida após a realização da eleição a que concorreu o candidato alcançado pela sentença, caso em que os votos serão contados para o partido pelo qual tiver sido feito o seu registro. (BRASIL, 1965). 
eleitor. Ela é perfeita em sua exteriorização e no modo como se realiza ou manifesta. A nulidade de que fala o Código Eleitoral é, nesses casos, efeito extrínseco de uma decisão judicial que não tem por objeto a conformidade do voto para com os requisitos legais ou o cumprimento de formalidades legais durante a votação. A materialidade da decisão do eleitor não é posta em questão. Ao contrário, a nulidade recai sobre votos existentes, materialmente perfeitos e, portanto, apuráveis, mas ineficazes porque dados a candidatos cujo registro foi indeferido.

Trata-se, assim, de nulidade que não poderia ser aferida pela Junta Eleitoral, também porque, em geral, só se a reconhece depois da apuração. Afinal, a invalidade prevista nos $\iint 3^{\circ}$ e $4^{\circ}$ do art. 175 do CE decorre do indeferimento do registro de candidatura ou do reconhecimento da inelegibilidade de candidato, pela Justiça Eleitoral, depois das eleições ou depois do fechamento das urnas eletrônicas. Se a decisão final de indeferimento do registro ou procedência do recurso contra expedição de diploma (RCED) for proferida "antes da preparação das urnas eletrônicas e o candidato nelas não tiver seu nome incluído, o problema da validade dos votos sequer chega a ser colocado." (GOMES, 2016, p. 845).

\subsubsection{Anulabilidades previstas no Código Eleitoral}

Também se observam inconsistências no tratamento dado ao Código Eleitoral à sanção de "anulabilidade". Ela é aplicada, indistintamente, ao mero desrespeito de formalidades do processo eleitoral, a irregularidades cuja repercussão é meramente individual (ou, ao menos, localizada), e também à prática de graves ilícitos eleitorais que repercutem na eleição como um todo. $\mathrm{O}$ art. 221, do CE, por exemplo, visa primariamente a proteger a autenticidade eleitoral em sentido formal. Ele prevê que a votação de seções específicas é anulável devido a vícios no procedimento, como no caso de extravio de documento e de restrição ao direito de fiscalizar ${ }^{11}$. Embora também aponte para possíveis ameaças à autenticidade eleitoral em sentido substantivo - no caso do uso de identidade falsa para se passar por eleitor

\footnotetext{
${ }^{11}$ Art. 221. É anulável a votação: I - quando houver extravio de documento reputado essencial; II - quando for negado ou sofrer restrição o direito de fiscalizar, e o fato constar da ata ou de protesto interposto, por escrito, no momento: III - quando votar, sem as cautelas do Art. 147, $₫ 2^{\circ}:$ a) eleitor excluído por sentença não cumprida por ocasião da remessa das folhas individuais de votação à mesa, desde que haja oportuna reclamação de partido; b) eleitor de outra seção, salvo a hipótese do Art. 145; c) alguém com falsa identidade em lugar do eleitor chamado. (BRASIL, 1965).
}

Resenba Eleitoral (Florianópolis), v. 21, n. 1, p. 69-94, nov. 2017 
e votar -, por se tratar de uma irregularidade isolada, os efeitos da anulação se circunscrevem à seção eleitoral afetada. Assim, apesar de tratadas como causas de anulação de votos pelo Código Eleitoral, as hipóteses do art. 221, do CE podem ser decretadas de ofício pela Junta Apuradora (REIS, 2012, p. 348). O mesmo aplica-se à anulação da votação em razão da existência de vícios externos verificados antes da abertura da urna, prevista no art. 165, do $\mathrm{CE}^{12}$.

Já o art. 222, do CE, o qual também trata da invalidação de votos, visa garantir a autenticidade eleitoral em sentido substantivo, e prevê hipóteses que tendem a impactar a eleição como um todo. $\mathrm{O}$ artigo diz que a votação é anulável quando viciada de falsidade, fraude, coação, abuso de poder econômico ou de autoridade, ou emprego de processo de propaganda ou captação de sufrágios vedados por lei. O objetivo principal da norma

${ }^{12}$ Art. 165. Antes de abrir cada urna a Junta verificará: I - se há indício de violação da urna; II - se a mesa receptora se constituiu legalmente; III - se as folhas individuais de votação e as folhas modelo 2 (dois) são autênticas; IV - se a eleição se realizou no dia, hora e local designados e se a votação não foi encerrada antes das 17 (dezessete) horas; V - se foram infringidas as condições que resguardam o sigilo do voto; VI - se a seção eleitoral foi localizada com infração ao disposto nos $\iint 4^{\circ}$ e $5^{\circ}$ do Art. 135; VII - se foi recusada, sem fundamento legal, a fiscalização de partidos aos atos eleitorais; VIII - se votou eleitor excluído do alistamento, sem ser o seu voto tomado em separado; IX - se votou eleitor de outra seção, a não ser nos casos expressamente admitidos; X - se houve demora na entrega da urna e dos documentos conforme determina o $\mathrm{n}^{\circ} \mathrm{VI}$, do Art. 154. XI - se consta nas folhas individuais de votação dos eleitores faltosos o devido registro de sua falta. $\int 1^{\circ} \mathrm{Se}$ houver indício de violação da urna, proceder-se-á da seguinte forma: I - antes da apuração, o presidente da Junta indicará pessoa idônea para servir como perito e examinar a urna com assistência do representante do Ministério Público; II - se o perito concluir pela existência de violação e o seu parecer for aceito pela Junta, o presidente desta comunicará a ocorrência ao Tribunal Regional, para as providências de lei; III - se o perito e o representante do Ministério Público concluírem pela inexistência de violação, far-se-á a apuração; IV - se apenas o representante do Ministério Público entender que a urna foi violada, a Junta decidirá, podendo aquele, se a decisão não for unânime, recorrer imediatamente para o Tribunal Regional; V - não poderão servir de peritos os referidos no Art. 36, \$3ํㅡㄴ nºs. I a IV. $\$ 2^{\circ}$ as impugnações fundadas em violação da urna somente poderão ser apresentadas até a abertura desta. S $3^{\circ}$ Verificado qualquer dos casos dos no II, III, IV e V do artigo, a Junta anulará a votação, fará a apuração dos votos em separado e recorrerá de ofício para

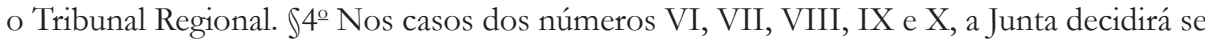
a votação é válida, procedendo à apuração definitiva em caso afirmativo, ou na forma do parágrafo anterior, se resolver pela nulidade da votação. $\int 5^{\circ}$ A junta deixará de apurar os votos de urna que não estiver acompanhada dos documentos legais e lavrará termo relativo ao fato, remetendo-a, com cópia da sua decisão, ao Tribunal Regional.” (BRASIL, 1965). 
é, assim, recompor a legitimidade das eleições que foi atingida por algum ilícito eleitoral (ZILIO, 2016, p. 68). Na verdade, hoje se entende que a abrangência da regra do art. 222 é tamanha, que ela se aplica, ao menos em tese, "a todas as ações de apuração de ilícitos cíveis eleitorais em sentido amplo.” (ZILIO, 2016, p. 68).

Curiosamente, tal não era o entendimento doutrinário e jurisprudencial dominante há algumas décadas; dadas as implicações decorrentes dessa mudança de paradigma, esse é o primeiro caso de mutação legal de interesse desta pesquisa, e que será discutido a seguir.

\section{Primeira Mutação Legal: eleições suplementares como consequência dos ilícitos eleitorais típicos}

A primeira mutação legal a ser estudada produziu precisamente a leitura segundo a qual as anulabilidades previstas no art. 222, do CE decorrem exclusivamente da prática dos ilícitos eleitorais típicos - abusos de poder, captação de sufrágio, condutas vedadas etc. - e, por isso, abrem possibilidade para invalidação da votação como um todo e da renovação das eleições na circunscrição inteira, mediante a convocação de eleições suplementares.

Ainda segundo essa leitura, as demais anulabilidades eleitorais, causadas por vícios no processo de votação que não pressupõem condutas eleitorais ilícitas, afetariam votos, cédulas e seções específicas, mas não a votação como um todo. Consequentemente, para além da hipótese de nulidade da votação obtida pelo candidato eleito cujo registro é indeferido depois das eleições ( $\$ 3^{\circ}$ do art. 175 do $\left.\mathrm{CE}\right)$, a única hipótese de anulabilidade que autorizaria a renovação das eleições seria a de cassação do registro, do diploma ou do mandato de candidato eleito, em virtude da prática de um ilícito eleitoral típico (art. 222 do CE).

$\mathrm{O}$ art. 222, do CE prevê que "É também anulável a votação, quando viciada de falsidade, fraude, coação, uso de meios de que trata o art. 237, ou emprego de processo de propaganda ou captação de sufrágios vedado por lei.” (BRASIL, 1965). Já o art. 237, do CE, por ele mencionado, dispõe: "A interferência do poder econômico e o desvio ou abuso do poder de autoridade, em desfavor da liberdade do voto, serão coibidos e punidos."

Atualmente, a leitura majoritária desses artigos os reduz aos ilícitos eleitorais típicos e às ações eleitorais típicas correspondentes a estes. 
A fraude e o abuso de poder econômico são causa de pedir da ação de impugnação do mandato eletivo (AIME); os abusos de poder econômico, político e de autoridade são causa de pedir da ação de investigação judicial eleitoral (AIJE); e a coação e a captação ilícita de sufrágio, causa de pedir da representação.

As ações eleitorais serão objeto da próxima seção. Por ora, foca-se nos ilícitos eleitorais típicos e na convocação de novas eleições deles decorrente.

\subsection{Renovação do Pleito x Eleições Suplementares}

A diferenciação entre anulabilidades decorrentes de ilícitos eleitorais, de um lado, e aquelas decorrentes de outros vícios no processo eleitoral já era reconhecida pela doutrina anterior. Entendia-se, porém, que o art. 222, do CE se referia indistintamente a ambos os tipos de anulabilidade. Ribeiro (1988, p. 412), por exemplo, defendia que o art. 222, do CE agrupava hipóteses muito distintas. Algumas levavam à "anulação de uma determinada seção eleitoral" - por exemplo, no caso de falsidade em que "alguém se apresenta perante uma mesa receptora portando título eleitoral, material ou ideologicamente adulterado" (RIBEIRO, 1988, p. 409), caso que se assemelha à da alínea "c" do inciso III do art. 221 do CE.

Outras hipóteses ocasionavam a invalidação "de todas as votações obtidas" para aquele cargo na circunscrição - por exemplo, no caso de abuso do poder de autoridade em que a "desvirtuada participação toma uma compleição mais genérica, não se localizando particularmente em determinada seção.” (RIBEIRO, 1988, p. 412).

A distinção entre a invalidação de seções eleitorais específicas e a invalidação das eleições para determinado cargo em toda a circunscrição possuía relevância prática. Embora ambas pudessem levar à convocação de novas eleições, a renovação poderia ser apenas parcial no primeiro caso. $\mathrm{Na}$ verdade, a doutrina reservava a expressão "eleições suplementares" exclusivamente para a renovação das eleições decorrentes da invalidação de seções eleitorais específicas, prevista no art. 187, do CE ${ }^{13}$. Ribeiro (1988, p. 388)

${ }^{13}$ Art. 187. Verificando a Junta Apuradora que os votos das seções anuladas e daquelas
cujos eleitores foram impedidos de votar, poderão alterar a representação de qualquer
partido ou classificação de candidato eleito pelo princípio majoritário, nas eleições mu-
nicipais, fará imediata comunicação do fato ao Tribunal Regional, que marcará, se for o
caso, dia para a renovação da votação naquelas seções. $\int 1^{\circ}$ Nas eleições suplementares
municipais observar-se-á, no que couber, o disposto no Art. 201 . $\$ 2^{-}$Essas eleições serão Resenha Eleitoral (Florianópolis), v. 21, n. 1, p. 69-94, nov. 2017 
definia como suplementares as eleições que se realizavam quando o total dos votos inválidos, em razão da anulação de seções específicas pela Junta Apuradora, fosse suficiente para "alterar a posição de partido pelo sistema de representação proporcional ou a classificação de candidato pelo sistema majoritário."

Para a doutrina anterior, portanto, nas eleições suplementares, o alcance da nova votação "fica circunscrito aos eleitores de seções anuladas, que são novamente convocados” (RIBEIRO, 1988, p. 319). Tal conclusão era confirmada pela jurisprudência do TSE, segundo a qual "Verificado que os votos anulados da seção eleitoral podem alterar a representação partidária na Câmara Municipal, deve o TRE marcar a realização de eleição suplementar para renovação da votação" (BRASIL, 1989a) e "Verificando que a votação da seção anulada, em decorrência da incoincidência de votos, poderá alterar a classificação de candidato eleito pelo princípio majoritário, determina-se a realização de eleição suplementar, nos termos do art. 187 do CE.” (BRASIL, 1989b).

Ainda hoje, o uso da expressão "eleições suplementares" para indicar exclusivamente as eleições convocadas nos termos do art. 187, do CE, isto é, em razão da invalidação de seções eleitorais específicas, é respaldado por autores como Reis (2012, p. 354-355) e Zilio (2016, p. 73). No entanto, tal sentido restrito não é referendado por outros juristas, como Gomes (2016, p. 847-853) e Neisser (2016, p. 434-435), e, curiosamente, foi abandonado pelo TSE, que passou a se valer da expressão "eleições suplementares” para tratar indistintamente da renovação das eleições em razão da anulação de seções específicas ou da invalidação das eleições como um todo.

É difícil traçar o ponto de virada na jurisprudência. Verifica-se, contudo, que, em 2003, a distinção era ainda observada:

Não se trata, tampouco, de eleição suplementar. Esta ocorre quando é necessário repetir-se a votação em alguma seção eleitoral que tenha sido anulada por um dos motivos previstos no capitulo VI do Código Eleitoral, que trata das nulidades da votação.

realizadas perante novas mesas receptoras, nomeadas pelo juiz eleitoral, e apuradas pela própria Junta que, considerando os anteriores e os novos resultados, confirmará ou invali-

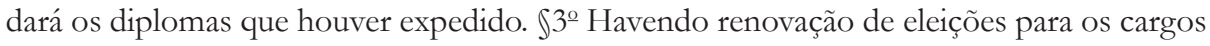
de prefeito e vice-prefeito, os diplomas somente serão expedidos depois de apuradas as eleições suplementares. $\int 4^{\circ}$ Nas eleições suplementares, quando ser referirem a mandatos de representação proporcional, a votação e a apuração far-se-ão exclusivamente para as legendas registradas." (BRASIL, 1965). 
Por certo que o caso dos autos não é de eleição suplementar, visto que todo o pleito majoritário foi renovado e não apenas algumas seções. (destaque nosso).

Já não o era mais, porém, em 2012, “Ocorrendo a vacância dos cargos de prefeito e de vice-prefeito no primeiro biênio, deverão ser convocadas eleições suplementares diretas para a complementação do mandato" (art. 81, da Constituição Federal). (BRASIL, 2012).

Uma possível explicação para essa mutação legal é a informatização das eleições. Com a implementação da urna eletrônica, superaram-se as fraudes relativamente comuns que afligiam a votação (JORGE, 2016, p. 78). E hipóteses como as previstas no caput e nos incisos do art. 175, do $\mathrm{CE}$, relativas à nulidade das cédulas de votação, passaram a ser raras, na prática. Isso não quer dizer, porém, que as normas relativas a invalidades dos meios físicos de votação se tornaram inaplicáveis. Em eleições municipais, a invalidação dos votos recebidos por uma única urna eletrônica pode impactar significativamente a eleição de vereadores e alterar a distribuição das cadeiras por partido ou coligação ${ }^{14}$. Por isso, merece atenção a redução de sentido que se operou no art. 222 do CE, sobre o que se falará a seguir.

\subsection{Anulabilidades não Decorrentes de Ilícitos Eleitorais Típicos}

O abandono do sentido restrito da expressão "eleições suplementares" pela doutrina majoritária e pela jurisprudência do TSE é digno de nota. No entanto, a mutação legal de maior relevância para a compreensão do sistema eleitoral das invalidades e da defesa da autenticidade das eleições se operou em relação a outro ponto: à crença, largamente dominante na doutrina e na jurisprudência contemporâneas, de que o art. 222, do CE só trata de ilícitos eleitorais típicos e que, portanto, a invalidação da votação nele prevista - e a eventual convocação de novas eleições - decorre exclusivamente da cassação do candidato eleito pela prática de conduta vedada, captação ilícita de sufrágio, abuso de poder etc.

Atualmente, a doutrina majoritária separa as causas de anulação das eleições em dois grupos (GOMES, 2016, p. 844-845; NEISSER, 2016,

\footnotetext{
${ }^{14}$ Veja-se, por exemplo, o caso das eleições de 2014 em Içara (SC), noticiado por Guimarães (2014) e pelo portal G1 (PERÍCIA, 2014), em que a anulação dos votos da urna eletrônica, causada por problemas técnicos, impactou a eleição de deputados.
} 
p. 437). O primeiro seria composto pelas hipóteses nas quais a invalidade dos votos decorre da condenação por ilícito eleitoral típico, que implique a cassação do registro de candidatura, do diploma ou do mandato eletivo. O segundo grupo seria formado pelas hipóteses de indeferimento do registro de candidatura ou recurso contra a expedição do diploma (RCED), em razão da falta de alguma condição de elegibilidade ou incidência de alguma causa de inelegibilidade. Com isso, afirma-se, implícita ou explicitamente, que "a aplicação do art. 224 [do CE] estará sempre vinculada à ocorrência de casos de perda de mandatos e diplomas por via judicial" (REIS, 2012, p. 353). Ou seja, supõe-se que a invalidade, e a renovação das eleições dela decorrente, é sempre efeito anexo ou externo, ou "decorrência natural", de uma decisão judicial.

Também a jurisprudência endossa tal entendimento, como demonstra a paradigmática decisão do TSE nos ED no RESPE 139-25, a convocação das novas eleições deve ocorrer:

[...] após a análise dos feitos pelo Tribunal Superior Eleitoral, no caso dos processos de registro de candidatura (LC 64/90, arts. $3^{2}$ e seguintes) em que haja o indeferimento do registro [...]; e

[...] após a análise do feito pelas instâncias ordinárias, nos casos de cassação do registro, do diploma ou do mandato, em decorrência de ilícitos eleitorais apurados sob o rito do art. 22 da Lei Complementar 64/90 ou em ação de impugnação de mandato eletivo. (BRASIL, 2016, destaque nosso).

Nega-se, portanto, a possibilidade de que a invalidade - declarada pela Junta Eleitoral - de seções eleitorais específicas acarrete, em conjunto, a renovação das eleições, também pela incidência do art. 224, do CE. Autores como Reis (2012, p. 354) e Zilio (2016, p. 73) afirmam expressamente que, no caso da invalidade de votos, cédulas e seções eleitorais, decorrente dos arts. 165, 220 e 221, do CE, realizam-se eleições suplementares, "com a convocação dos eleitores inscritos nas sessões atingidas” (REIS, 2012, p. 355); apenas no caso da invalidação da votação atribuída a determinados candidatos, procede-se como previsto no art. 224, do CE. Disso decorre que o art. 224, do CE nunca será aplicado a outros casos que não àqueles de indeferimento de registro de candidatura, nos termos do $₫ 3^{\circ}$ do art. 175 do CE, ou cassação do registro, do diploma ou do mandato eletivo pela Justiça Eleitoral, nos termos do art. 222 do CE (REIS, 2012, p. 355). 
O que se pretende destacar aqui é que se operou, na doutrina e na jurisprudência, uma redução silenciosa do sentido do art. 222, do CE - mais especificamente, do escopo ou hipótese de incidência dele. A vinculação das anulabilidades previstas nesse artigo à cassação de registros de candidatura, diplomas e mandatos - como se ele tratasse exclusivamente de ilícitos eleitorais típicos e não incluísse outros vícios do processo eleitoral - não era óbvia há três décadas. Em oposição ao entendimento hoje dominante, Ribeiro (1988, p. 319) dava destaque à possibilidade de que a anulação de várias seções eleitorais comprometesse a votação na circunscrição eleitoral como um todo e implicasse na "renovação total do pleito, tornando-se insubsistente a votação que não esteja contagiada diretamente por vício nulificador, nos termos do que preceitua o artigo 224 do Código Eleitoral."

$\mathrm{Na}$ realidade, a incidência do art. 224 , do CE e a realização de novas eleições em toda a circunscrição, quando comprometida mais da metade dos votos, eram acarretadas não apenas pelas hipóteses de anulabilidade do art. 222, do CE, incluindo as que não pressupõem ilícitos eleitorais típicos, mas também pelas hipóteses de nulidade do art. 175, do CE por vícios no processo de votação. Esses votos nulificados ou anulados por diferentes causas, pela Junta Apuradora ou por decisão judicial, se somavam para fins de determinar se as eleições seriam válidas. Assim é que, nos dizeres de Ribeiro (1988, p. 412), "Votos marcados com sigla de partido que não registrara candidato a prefeito" - o que, por força do inciso III do art. 175 do CE, implica em nulidade, por conterem as cédulas expressões, frases ou sinais que possam identificar o voto - ocasionavam a renovação das eleições, nos termos do art. 224, do CE, desde que a nulidade excedesse "mais da metade o total da votação." (BRASIL, 1973a).

Desde pelo menos a década de 1970, a jurisprudência do TSE havia se firmado no sentido "da anulação da eleição majoritária, qualquer que [fosse] o motivo da nulidade da votação, votos ou cédulas, desde que se apur[asse] o excesso de mais da metade sobre o total do comparecimento." (BRASIL, 1973a). Em mais de uma oportunidade o Tribunal se manifestou no sentido de que "Para a nulidade da eleição, tratada no art. 224 do Código Eleitoral, concorrem não só as nulidades da votação (art. 220 a 222), quanto às do voto (art. 175).” (BRASIL, 1973b). A jurisprudência do TSE é farta em decisões como essa pelo menos até o final da década de $1990{ }^{15}$.

${ }^{15}$ Ver, por exemplo, o Mandado de Segurança (MS) 2.624, julgado em 1998 (BRASIL, 1998). 
É verdade que a renovação total das eleições nessa situação era, e é, relativamente remota. Mais provável é que a invalidade de votos, urnas e seções específicas fique circunscrita e não gere repercussões que exijam a renovação total das eleições. Todavia, faz-se necessário reconhecer que ela permanece como possibilidade decorrente do sistema eleitoral das invalidades e da defesa da autenticidade das eleições vigente ainda hoje, ao lado da renovação parcial, prevista no art. 187 do CE.

\section{Segunda Mutação Legal: invalidade da votação exclusi- vamente via ações eleitorais típicas}

Outro importante ponto em relação ao qual se operou uma mutação legal diz respeito à existência de meios autônomos para a decretação da invalidade de atos eleitorais. Com o tempo esses meios próprios - as arguições de invalidade - foram silenciosamente deixados de lado pela doutrina no tratamento do sistema de invalidações previsto no Código Eleitoral. Isso ocorreu, não coincidentemente, à medida que as ações eleitorais típicas (AIME, AIJE e representações específicas), destinadas a apurar os ilícitos eleitorais (conduta vedada, abuso de poder, captação de sufrágio etc.), ganharam importância, e a cassação de candidatos eleitos passou a ocupar posição de relevo no horizonte de atribuições e competências da Justiça Eleitoral. Nessas ações, a invalidação dos votos dos candidatos cassados não constitui propriamente o pedido ou a causa de pedir da demanda, senão efeito extrínseco da condenação ou do reconhecimento do ilícito cometido.

O aumento dos casos de condenação de candidatos pela prática de ilícitos eleitorais típicos, que não passou despercebido à doutrina ${ }^{16}$, decorreu de sucessivas reformas legislativas que, desde pelo menos 1999, espalharam pela legislação eleitoral as sanções de cassação de registro ou de diploma (JORGE, 2016, p. 77). Em virtude de tais alterações,

[...] houve uma mudança de foco das ações eleitorais, passando-se de uma tutela repressiva (pós-eleitoral), tal como desenhada pelo Código de 1965, para uma tutela preventiva, [...] como há muito já reclamava parte da doutrina, que atentamente se preocupava com os efeitos deletérios dos vícios na formação da vontade do eleitor e com a ineficiência doa arcabouço jurídico eleitoral. (JORGE, 2016, p. 77).

${ }^{16}$ Vejam-se, por exemplo, Espíndola (2012, p. 446-447) e Neisser (2016, p. 433-434). 
Como originalmente desenhado pelo Código Eleitoral, as ações eleitorais típicas não eram a via mais comum para a invalidação de votos ou da votação. Em sua obra, Ribeiro (1988, p. 372, 379-381, 397) dava destaque aos recursos, impugnações e arguições especialmente designadas a decretar invalidades eleitorais. Citam-se, por exemplo, a arguição de invalidade perante a Junta Apuradora, antes da abertura da urna, em razão da existência de vícios externos que pudessem comprometer a validade da votação, prevista no art. 165, do CE; as impugnações e os recursos durante a apuração, previstas nos arts. 169 a 172, do CE; e, finalmente, as arguições de nulidade de atos cuja invalidade não houvesse sido declarada de ofício pela Junta Eleitoral, previstas no art. 223 do $\mathrm{CE}^{17}$.

$\mathrm{O}$ autor defendia a possibilidade de arguição de invalidade mesmo nas hipóteses do art. 222, do CE, isto é, nos casos de votação atingida por falsidade, fraude, coação, interferência do poder econômico, desvio ou abuso do poder de autoridade, ou emprego de processo de propaganda ou captação de sufrágios vedados por lei. Nas palavras dele, "a ocorrência de qualquer dos casos aflorados rende ensejo à anulação dos votos, desde que sejam arguidos em tempo hábil, evitando os efeitos letais da preclusão." (RIBEIRO, 1988, p. 416).

Esgotado o prazo para interposição do recurso próprio, a arguição só seria possível "em nova fase que se venha a oferecer no fluxo do processo eleitoral.” (RIBEIRO, 1988, p. 397). Em qualquer caso, uma vez provocada, a Justiça Eleitoral proferiria uma decisão "de eficácia constitutiva negativa", que declararia a invalidade, "subsistindo os efeitos produzidos até o instante em que é emitido o ato anulatório.” (RIBEIRO, 1988, p. 397).

Não havia ressalva quanto à possibilidade dessas arguições, mas sim quanto à eficácia delas. Para Ribeiro (1988, p. 412), a ineficácia de tais medidas era patente, particularmente no caso de abuso de poder político ou de autoridade, pois, na prática, revelava-se "improvável” que se conseguisse

${ }^{17}$ Art. 223. A nulidade de qualquer ato, não decretada de ofício pela Junta, só poderá ser arguida quando de sua prática, não mais podendo ser alegada, salvo se a arguição se basear em motivo superveniente ou de ordem constitucional. \$1을 Se a nulidade ocorrer em fase na qual não possa ser alegada no ato, poderá ser arguida na primeira oportunidade que para tanto se apresente. $\ 2^{\circ}$ Se se basear em motivo superveniente deverá ser alegada imediatamente, assim que se tornar conhecida, podendo as razões do recurso ser aditadas no prazo de 2 (dois) dias. $\int 3^{\circ} \mathrm{A}$ nulidade de qualquer ato, baseada em motivo de ordem constitucional, não poderá ser conhecida em recurso interposto fora do prazo. Perdido o prazo numa fase própria, só em outra que se apresentar poderá ser arguida. (BRASIL, 1965). 
demonstrar "a mobilização abusiva do arsenal estatal em proveito de determinados candidatos, a ponto de invalidar todas as votações obtidas que serão atingidas." De acordo com o autor, mais provável era que a invalidação da votação ocorresse como efeito extrínseco da declaração superveniente de inelegibilidade. Nessa segunda hipótese, "não estará sendo arguida a anulação das votações, mas promovida a declaração de inelegibilidade dos candidatos implicados, e, por via de consequência, anuladas as votações que pessoalmente lhes tenham sido atribuídas”, em aplicação do $₫ 3^{\circ}$ do art. 175 do CE (RIBEIRO, 1988, p. 412).

Esse entendimento contrasta com a prática atual. Como antecipado, a invalidade da votação é, para a doutrina e a jurisprudência contemporâneas, sempre efeito anexo de uma decisão judicial que não tem por objeto a arguição de nulidade ou anulabilidade e que, portanto, prescinde de um pedido nesse sentido ou da provocação da parte interessada. As hipóteses do art. 222, do CE, de invalidade decorrente de ilícitos eleitorais típicos, aparecem na literatura especializada exclusivamente como efeito externo da decisão de procedência das ações eleitorais típicas. E as hipóteses do caput e dos $\iint 1^{\varrho}$ e $2^{\circ}$ do art. 175 do CE perdem importância com a adoção do sistema eletrônico de votação. A nulidade a que alude o caput do art. 224 seria, então, apenas aquela prevista:

a) no $\$ 3^{\circ}$ do art. 175 do $\mathrm{CE}$, para o indeferimento do registro de candidato, posterior às eleições ou ao fechamento das urnas, em sede de RCED ou de uma ação de impugnação do registro de candidatura (AIRC); e,

b) no art. 222, do CE, para a cassação do registro, do diploma ou do mandato de candidato eleito, em sede de uma ação eleitoral típica (AIJE, AIME ou representação prevista no art. 22 da LC 64/90).

Foi isso o que o TSE definiu no julgamento dos ED no RESPE 139-25 (BRASIL, 2016). Ou seja, de acordo com o entendimento hoje majoritário, senão unânime, a invalidação decorreria da decisão de procedência "tanto nas ações de arguição de inelegibilidade (AIRC e RCED) como nas ações de combate aos ilícitos eleitorais (AIJE, AIME e representação do art. 30-A, art. 41-A, arts. 73/77, todos da LE)." (ZILIO, 2016, p. 73). Nada se diz, na doutrina contemporânea, sobre as arguições de invalidade, que, desde a adoção do sistema eletrônico de votação e da multiplicação das ações eleitorais típicas, desapareceram também da jurisprudência. 


\section{Considerações Finais}

$\mathrm{O}$ artigo se dedicou a analisar duas mutações legais operadas nas últimas décadas no sistema eleitoral de invalidades e de defesa da autenticidade das eleições, pela doutrina eleitoralista e pela jurisprudência dos tribunais eleitorais. Por analogia ao conceito de mutação constitucional de Jellinek (1991), as mutações legais se definem como mudanças nas normas jurídicas infraconstitucionais provocadas não pelos legisladores, mas pelos intérpretes. Independem de alteração textual formal e isso as diferencia das reformas legislativas. Ademais, ocorrem sem que os agentes que as operam demonstrem consciência de que o fazem, e isso as afasta do ativismo judicial.

Em particular, as mutações legais estudadas no artigo implicaram sensíveis alterações no Direito Eleitoral, sem que o TSE enfrentasse e superasse expressamente as premissas de sua jurisprudência histórica sobre o tema. Os dois exemplos discutidos, relativos às hipóteses e aos procedimentos que autorizam a renovação das eleições, ilustram bem os problemas sistêmicos trazidos pelas mutações.

No primeiro caso, reduziram-se o alcance e o sentido do art. 222, do CE, que passou a ser lido como se as causas de anulabilidade nele previstas se restringissem aos ilícitos eleitorais típicos (abuso de poder, conduta vedada, captação de sufrágio etc.) e não incluíssem outros vícios do processo eleitoral, relativos aos meios físicos de votação.

No segundo, desapareceram, da doutrina e da jurisprudência, os meios autônomos para a decretação da invalidade de atos eleitorais, as arguições de invalidade. Ambas as mutações foram causadas por fatos externos à argumentação jurídica: a implementação do sistema eletrônico de votação e das urnas eletrônicas, e o aumento dos casos de cassação de registro e de diploma, em razão da profusão de ações eleitorais que a pleiteiam.

A repercussão das duas mutações na compreensão das normas jurídicas a que se referem é, porém, notável. Com base nelas, constituiu-se o paradigma hoje dominante, condensado pelo TSE nos ED no RESPE 13925 , segundo o qual, a convocação das novas eleições, nos termos do art. 224, do CE, deve ocorrer exclusivamente em virtude do indeferimento do registro, no caso dos processos de registro de candidatura, ou da cassação do registro, do diploma ou do mandato, em decorrência de ilícitos eleitorais apurados em AIJE, AIME ou representações que seguem o rito do art. 22, da LC 64/90. 
Uma vez lançada luz sobre o fato de o Direito Eleitoral modificar-se não somente pelas reformas eleitorais que se sucedem a cada eleição, mas também, pelas mutações legais que afetam institutos nucleares desse ramo jurídico, cumpre aos eleitoralistas, nas cortes ou fora delas, dedicar ao fenômeno a atenção que merece. Uma teoria eternamente deslumbrada perante a radiante presença dos tribunais eleitorais, e uma jurisprudência sempre cambiante e sem consciência de si mesma e de sua história, em nada contribuem para a segurança jurídica dos cidadãos e para a garantia dos direitos fundamentais que eles confiam à guarda da Justiça Eleitoral.

No caso das mutações aqui discutidas, o fato de o paradigma hoje dominante não estar assentado em bases conceituais e jurisprudenciais sólidas é especialmente preocupante, na medida em que o que está em jogo, em se tratando da aplicação do art. 224, do CE, é a validade, ou não, da vontade popular conforme manifestada nas urnas.

\section{Referências}

ALVIM, F. F. Integridade eleitoral: significado e critérios de qualificação. Revista Ballot, v. 1, n. 2, p. 213-228, 2015.

ANDRADE NETO, J. Controle e Judicialização das Eleições: A legitimidade de juízes e tribunais eleitorais para decidirem "questões políticas". In: MORAES, F.; SALGADO, E. D.; AIETA, V. S. (Eds.). Justiça Eleitoral, Controle das Eleições e Soberania Popular. Curitiba: Íthala, 2016a. p. 277-315.

. Participante ou observador? Uma escolha entre duas perspectivas metodológicas de estudo e aplicação do Direito. Revista Direito GV, v. 12, n. 3, p. 869-891, dez. 2016b.

BRAMRAITER, J. Os Reais Efeitos do Voto Nulo na Atualidade e seu Reflexo para o Regime da Democracia Representativa no Brasil. Revista Estudos Legislativos, v. 7, n. 7, p. 61-93, 2013.

BRASIL. Lei n. 4.737, de 15 de julho de 1965. Institui o Código Eleitoral. D.O. de 19 jul. 1965, p. 6746.

. Tribunal Superior Eleitoral. Acórdão 5.361 no Recurso Especial Eleitoral 4.005 / AL, de 5 abr. 1973. Relator: Min. Márcio Ribeiro. Boletim Eleitoral, vol. 263, Tomo 1. Brasília, DF, 1973a.

Tribunal Superior Eleitoral. Agravo de Instrumento 4.069 / SP, de 27 set. 1973. Relator: Min. Carlos Eduardo de Barros Barreto. Boletim Eleitoral, vol. 268, Tomo 1. Brasília, DF, 1973b. 
. Constituição da República Federativa do Brasil de 1988. DOU, 5 out. 1988, p. 1.

. Tribunal Superior Eleitoral. Acórdão 10.854 no Recurso Especial Eleitoral 8.404 - PR, de 17 ago. 1989. Relator: Min. Romildo Bueno De Souza. Diário de Justiça, 13 out. 1989. Brasília, DF, 1989a.

. Tribunal Superior Eleitoral. Acórdão 10.501 no Recurso Especial Eleitoral 8.152 / SC, de 28 fev. 1989. Relator: Min. Antônio Vilas Boas Teixeira de Carvalho. Diário de Justiça, 10 mar. 1989. Brasília, DF, 1989b.

. Tribunal Superior Eleitoral. Mandado de Segurança 2624 / AM, de 5 mai. 1998. Relator: Min. Eduardo Andrade Ribeiro de Oliveira. DJ, 29/6/1998, p. 71. Brasília, DF, 1998.

. Tribunal Superior Eleitoral. Acórdão no Recurso Especial Eleitoral 21.141 / GO, de 15 mai. 2003. Relator: Min. Fernando Neves da Silva. Diário de Justiça, 29 ago. 2003. Brasília, DF, 2003.

. Tribunal Superior Eleitoral. Acórdão no Mandado de Segurança 147.854 / SC, de 20 mar. 2012. Relator: Min. Marcelo Henriques Ribeiro de Oliveira. Diário de Justiça eletrônico, Tomo 96, 23 mai. 2012. Brasília, DF, 2012.

. Tribunal Superior Eleitoral. Embargos de Declaração no Recurso Especial Eleitoral 139-25 / RS, de 27 nov. 2016. Relator: Min. Henrique Neves da Silva. Publicado na sessão de 28 nov. 2016. Brasília, DF, 2016.

BULOS, U. L. Da reforma à mutação constitucional. Revista de informação legislativa, v. 33, n. 129, p. 25-43, jan./mar. 1996.

CRUVINEL, D. M. Judicialização da política e ativismo judicial: um esforço pela organização do cenário. Dissertação (mestrado). Belo Horizonte: Universidade Federal de Minas Gerais (UFMG), 2013.

ESPÍNDOLA, R. S. Justiça brasileira contramajoritária e soberania popular: a democrática vontade das urnas e a autocrática vontade judicial que a nulifica.

Eleições \& Cidadania, v. 4, n. 4, p. 98-125, 2012.

GOMES, J. J. Invalidade no direito eleitoral: nulidade e anulabilidade de votos. Revista Brasileira de Direito Eleitoral, v. 1, n. 1, p. 63-104, jul. 2009. . Direito eleitoral. 4. ed. rev., atual. e ampl. São Paulo, SP: Del Rey, 2010. Atlas, 2016.

Direito eleitoral. 12. ed. rev., atual. e ampl. São Paulo, SP: Gen, 
GRESTA, R. M. et al. Por que a Lei da Ficha Limpa incide sobre situações jurídicas constituídas antes de sua vigência: duas objeções superadas. In: SOARES, I. A. N. et al. (Eds.). Coletânea de Artigos Jurídicos NAP 2011. Curitiba: CRV, 2012.

GUIMARÃES, T. Urna que quebrou e perdeu 287 votos pode mudar a eleição em SC. Folha de S. Paulo, São Paulo, 31 out. 2014. Disponível em: <http://www1.folha.uol.com.br/poder/2014/10/1541083-urna-que-quebrou-e-perdeu-287-votos-pode-mudar-eleicao-em-sc.shtml>. Acesso em: 20 mai. 2017.

JELLINEK, G. Reforma y Mutación de la Constitución. Madrid: Centro de Estudios Constitucionales, 1991.

JORGE, F. C. A ação eleitoral como tutela dos direitos coletivos e a aplicação subsidiária do microssitema processual coletivo e do Código de Processo Civil. In: TAVARES, A. R.; AGRA, W. de M.; LUCON, P. H. dos S. (Eds.). O Direito Eleitoral e o Novo Código de Processo Civil. Belo Horizonte: Fórum, 2016. p. 456.

MELLO, M. B. de. Teoria do Fato Jurídico: Plano da validade. 7 ed. rev. e atual. São Paulo: Saraiva, 2006.

NEISSER, F. A Ação de Ressarcimento de Danos Causados à União no Caso da Anulação de Eleições pela Justiça Eleitoral. In: AGRA, W. de M.; PEREIRA, L. F.; TAVARES, A. R. (Eds.). O Direito Eleitoral e o Novo Código de Processo Civil. Belo Horizonte: Fórum, 2016. p. 422-466.

PEDRA, A. S. Teoria da mutação constitucional: limites e possibilidades das mudanças informais da constituição a partir da teoria da concretização. Tese (doutorado em Direito). São Paulo: Pontifícia Universidade Católica de São Paulo (PUC-SP), 2009.

PEDRON, F. Q. Mutação constitucional na crise do positivismo jurídico: história e crítica do conceito no marco da teoria do direito como integridade. Belo Horizonte: Arraes, 2012.

PERÍCIA em urna de Içara pode mudar resultado de deputados eleitos em SC. G1, 31 out. 2014. Disponível em: <http://g1.globo.com/sc/santa-cata$\mathrm{rina} /$ noticia/2014/10/pericia-em-urna-de-icara-pode-resultar-em-troca-de-politicos-eleitos.html>. Acesso em: 10 mai. 2017.

REIS, M. J. O Novo \3o do art. 224 do Código Eleitoral e a posse do segundo colocado. Eleições \& Cidadania, v. 4, n. 4, p. 343-364, 2012. 
RIBEIRO, F. Direito Eleitoral. 3. ed. Rio de Janeiro: Forense, 1988.

SALGADO, E. D. Princípios constitucionais eleitorais. Belo Horizonte: Fórum, 2010.

SCHREIBER, A. Novos paradigmas da responsabilidade civil: da erosão dos filtros da reparação à diluição dos danos. São Paulo: Atlas, 2013.

VECCHI, C. B. Mutação constitucional: A origem de um conceito problemático. Dissertação (mestrado em Direito). Rio de Janeiro: Pontifícia Universidade Católica do Rio de Janeiro (PUC-Rio), 2005.

ZILIO, R. L. Nulidade dos votos no sistema proporcional: eficácia e efeitos da decisão judicial. Revista Brasileira de Direito Eleitoral, v. 5, n. 8, p. 91-120, jan.-jun. 2013.

Direito Eleitoral. 5. ed. Porto Alegre: Verbo Jurídico, 2016.

João Andrade Neto - Doutor em Direito com distinção (Summa Cum Laude) pela Universität Hamburg (UHH) / Fakultät für Rechtswissenschaft. Mestre em Direito pela Universidade Federal de Minas Gerais (UFMG), na Linha de Pesquisa Poder e Cidadania no Estado Democrático de Direito, com ênfase em Direito Constitucional, Eleitoral e Teoria do Estado. Analista Judiciário no Gabinete V da Assessoria Jurídica dos Juízes-Membros do Tribunal Regional Eleitoral de Minas Gerais (TRE-MG). Professor de Direito Constitucional e Eleitoral. 